Energy Research Journal 2 (1): 22-28, 2011

ISSN 1949-0151

(C) 2011 Science Publications

\title{
Design of a Fuzzy Logic Sliding mode Model Following Controller for a Brushless DC Servomotor Drivers
}

\author{
Phongsak Phakamach \\ Department of Electronics Engineering, \\ Faculty of Engineering, North Eastern University, Thailand
}

\begin{abstract}
Problem statement: A brushless DC servomotor position control system using a fuzzy logic sliding mode model following controller or FLSMFC is presented. Approach: The FLSMFC structure consists of an integrator and variable structure system. Results: The integrator ensures the elimination of steady state error due to step and ramp command inputs, while the fuzzy control would maintain the insensitivity to parameter variation and disturbances. The FLSMFC strategy is implemented and applied to a position control of a brushless DC servomotor. Conclusion/Recommendations: Experimental results indicated that FLSMFC system performance with respect to the sensitivity to parameter variations is greatly reduced. Also, its can achieve a rather accurate servo tracking and avoids the chattering phenomenon.
\end{abstract}

Key words: Sliding mode control, fuzzy logic, brushless DC servomotor

\section{INTRODUCTION}

Recently years, advancements in magnetic materials, semiconductor power devices and control theory have made the permanent magnet motor servo drive play an important role in motion control applications (Krause et al., 2002). In the servo applications, significant parameter variations arise from often unknown loads. A conventional linear controller may not assure satisfactory requirements.

It has been a subject of active research to design control systems which are insensitive to plant uncertainties and external disturbances. One of the most attractive approaches to deal with this problem is the so called Variable Structure Control (VSC) or Sliding Mode Control (SMC). The important feature in VSC is what is termed sliding mode. The VSC approach possesses other salient advantages such as high speed of response, good transient performance and no need for precise knowledge of the controlled plant. Although the conventional VSC approach has been applied successfully in many applications (Utkin et al., 2009; Hung et al., 1993), it cannot perform well in servo applications where the system is designed to track a command input. In order to improve tracking performance, the Integral Variable Structure Control or IVSC approach, presented in (Chern and Wang, 1995; Chern and Chang, 1997), combines an integral controller with the conventional VSC. The IVSC approach can eliminate the steady tracking error due to a step command input. However, IVSC yields the error when the system has to follow a changing command input, e.g., a ramp input. Note that, this kind of input is generally encountered in servo control applications. The Modified Integral Variable Structure Control or MIVSC approach, proposed in (Chen et al., 2009; Phakamach and Akkaraphong, 2003), uses a double integral action to solve this problem. Although, the MIVSC method can give a better tracking performance than the IVSC method does at steady state, its performance during transient period needs to be improved.

Fuzzy control is a practical control method which imitates human being fuzzy reasoning and decision making processes. Fuzzy logic control is derived from the fuzzy logic and fuzzy set theory that were introduced in 1965 by Professor Lotfi A. Zadeh of the University of California at Berkeley. Fuzzy logic control can be applied in many disciplines such as data analysis, engineering and other areas that involve a high level of uncertainty, complexity or nonlinearity. In engineering, engineers can use the fundamentals of fuzzy logic and fuzzy set theory to create the pattern and the rules, then design the fuzzy controllers, Finally, the output response of many systems can be improved by using a fuzzy controller (Thongchai, 2002; Thongchai et al., 2001). The method is applicable to conduct robustness control over target for which a mode is hard to be established. The final program form of the method is simple and easy to achieve. Therefore, combining fuzzy control with the VSC would maintain the insensitivity of sliding mode control to parameter perturbation and external disturbances while in the mean time effectively eliminate the chattering phenomenon.

This study presents the design and implementation of brushless DC servomotor position control systems using the Fuzzy Logic Sliding mode Model Following Controller or FLSMFC approach. This approach, which is the extension of IVSC approach, incorporates a feed forward path and fuzzy control to improve the dynamics response for command tracking and strong robustness. 


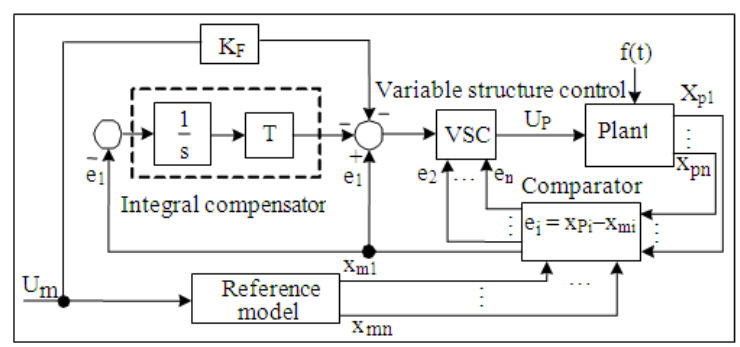

Fig. 1: The structure of FLSMFC system

Also, it can achieve a rather accurate servo tracking and is fairly robust to plant parameter variations and external load disturbances. Experimental results are presented for demonstrating the potential of the proposed scheme and the tracking performance can be remarkably improved.

Design of FLSMFC system: The structure of FLSMFC is shown in Fig. 1 can be described by the following equation of state Eq. 1:

$$
\begin{aligned}
& \dot{\mathrm{x}}_{\mathrm{i}}=\mathrm{x}_{\mathrm{i}+1}, \mathrm{i}=1, \ldots, \mathrm{n}-1 \\
& \dot{\mathrm{x}}_{\mathrm{n}}=-\sum_{\mathrm{i}=1}^{\mathrm{n}} \mathrm{a}_{\mathrm{i}} \mathrm{x}_{\mathrm{i}}+\mathrm{bU}-\mathrm{f}(\mathrm{t}) \\
& \dot{\mathrm{x}}_{0}=\left(\mathrm{r}-\mathrm{x}_{1}\right)
\end{aligned}
$$

The switching function $\sigma$ is given by Eq. 2:

$$
\sigma=\mathrm{c}_{1}\left(\mathrm{x}_{1}-\mathrm{Tx}_{0}-\mathrm{rK}_{\mathrm{F}}\right)+\sum_{\mathrm{i}=2}^{\mathrm{n}} \mathrm{c}_{\mathrm{i}} \mathrm{x}_{\mathrm{i}}
$$

Where:

$$
\begin{aligned}
\mathrm{C}_{\mathrm{i}}>0, \mathrm{C}_{\mathrm{n}} & =1 \\
\mathrm{~T} & =\text { Integral time }
\end{aligned}
$$

The control signal, $\mathrm{U}$ can be determined as follows, from (1) and (2), we have Eq. 3:

$$
\dot{\sigma}=-c_{1} T\left(r-x_{1}\right)+\sum_{i=2}^{n} c_{i-1} x_{i}-\sum_{i=1}^{n} a_{i} x_{i}+b U-f(t)
$$

Let:

$a_{i}=a_{i}^{0}+\Delta a_{i} ; i=1, \ldots, n$

and

$\mathrm{b}=\mathrm{b}^{0}+\Delta \mathrm{b} ; \mathrm{b}^{0}>0, \Delta \mathrm{b}>-\mathrm{b}^{0}$

The control signal can be separated into Eq. 4:

$\mathrm{U}=\mathrm{U}_{\mathrm{eq}}+\mathrm{U}_{\mathrm{fu}}$
This condition results in Eq. 5:

$$
U_{e q}=\left\{c_{1} T\left(r-x_{1}\right)-\sum_{i-2}^{n-1} c_{i-1} x_{i}+\sum_{i=1}^{n-1} a_{i}^{0} x_{i}\right\} / b^{0}
$$

The transfer function when the system is on the sliding surface can be shown as Eq. 6:

$$
H(s)=\frac{X_{1}(s)}{R(s)}=\frac{\alpha_{n}}{s^{n}+\alpha_{1} s^{n-1}+\ldots+\alpha_{n-1} s+\alpha_{n}}
$$

The transient response of the system can be determined by suitably selecting the poles of the transfer function Eq. 7:

Let:

$\mathrm{s}^{\mathrm{n}}+\alpha_{1} \mathrm{~s}^{\mathrm{n}-1}+\ldots+\alpha_{\mathrm{n}-1} \mathrm{~s}+\alpha_{\mathrm{n}}=0$

Be the desired characteristic equation (closed-loop poles), the coefficient $\mathrm{C}_{1}$ and $\mathrm{T}$ can be obtained by:

$$
\mathrm{C}_{\mathrm{n}-1}=\alpha_{1}, \mathrm{C}_{1}=\alpha_{\mathrm{n}-1} \text { and } \mathrm{T}=\alpha_{\mathrm{n}} / \alpha_{\mathrm{n}-1}
$$

Design of fuzzy logic controller: By the definition Eq. 8:

$$
\begin{aligned}
\mathrm{U}_{\mathrm{fu}}= & \mathrm{k}_{1}\left(\mathrm{x}_{1}-\mathrm{Tx}_{0}-\mathrm{rK}_{\mathrm{F}}\right)+\sum_{\mathrm{i}=2}^{\mathrm{n}} \mathrm{k}_{\mathrm{i}} \mathrm{x}_{\mathrm{i}}+\mathrm{k}_{\mathrm{n}+1} \\
& +\mathrm{K}\left[\Delta \mathrm{k}_{1}\left(\mathrm{x}_{1}-\mathrm{Tx}_{0}-\mathrm{rK} \mathrm{K}_{\mathrm{F}}\right)\right]+\sum_{\mathrm{i}=2}^{\mathrm{n}} \mathrm{k}_{\mathrm{i}} \mathrm{x}_{\mathrm{i}}
\end{aligned}
$$

$\mathrm{U}_{\mathrm{fu}}$ is required to guarantee the existence of the sliding mode under the plant parameter variations in $\Delta \mathrm{a}_{\mathrm{i}}$ and $\Delta \mathrm{b}$ and the disturbances $\mathrm{f}(\mathrm{t})$. Among them:

$$
\begin{aligned}
& \mathrm{k}_{1}= \begin{cases}\alpha_{1} & \text { if }\left(\mathrm{x}_{1}-\mathrm{Tx}_{0}-\mathrm{rK}_{\mathrm{F}}\right) \sigma>0 \\
\beta_{1} & \text { if }\left(\mathrm{x}_{1}-\mathrm{Tx}_{0}-\mathrm{rK}_{\mathrm{F}}\right) \sigma<0\end{cases} \\
& \mathrm{k}_{\mathrm{i}}=\left\{\begin{array}{ll}
\alpha_{\mathrm{i}} & \text { if } \mathrm{x}_{\mathrm{i}} \sigma>0 \\
\beta_{\mathrm{i}} & \text { if } \mathrm{x}_{\mathrm{i}} \sigma<0
\end{array}, \mathrm{i}=2, \ldots, \mathrm{n}\right. \text { and } \\
& \mathrm{k}_{\mathrm{n}+1}=\left\{\begin{array}{lll}
\alpha_{\mathrm{n}+1} & \text { if } & \sigma>0 \\
\beta_{\mathrm{n}+1} & \text { if } & \sigma<0
\end{array}\right.
\end{aligned}
$$

According to (3), we know Eq. 9:

$$
\begin{aligned}
& \dot{\sigma} \quad=-c_{1} T\left(r-x_{1}\right)+\sum_{i=2}^{n} c_{i-1} x_{i}-\sum_{i=1}^{n} a_{i} x_{i}+b U-f(t) \\
& \text { and } U=U_{e q}+k_{1} T\left(r-x_{1}\right)-\sum_{i-2}^{n-1} k_{i} x_{i}
\end{aligned}
$$

The condition for the existence of a sliding mode is known to be Eq. 10:

$\sigma \dot{\sigma}<0$ 
In order for (10) to be satisfied, the following conditions must be met Eq. 11a and b:

$$
\mathrm{k}_{\mathrm{i}}=\left\{\begin{array}{l}
\alpha_{\mathrm{i}}\left\langle\operatorname { I n f } \left[\Delta \mathrm{a}_{\mathrm{i}}-\mathrm{a}_{\mathrm{i}}^{0} \Delta \mathrm{b} / \mathrm{b}^{0}+\mathrm{c}_{\mathrm{i}-1} \Delta \mathrm{b} / \mathrm{b}^{0}\right.\right. \\
\left.-\mathrm{c}_{\mathrm{i}}\left(\mathrm{c}_{\mathrm{n}-1}-\mathrm{a}_{\mathrm{n}}^{0}\right)\left(1+\Delta \mathrm{b} / \mathrm{b}^{0}\right)\right] / \mathrm{b} \\
\beta_{\mathrm{i}}>\operatorname{Sup}\left[\Delta \mathrm{a}_{\mathrm{i}}-\mathrm{a}_{\mathrm{i}}^{0} \Delta \mathrm{b} / \mathrm{b}^{0}+\mathrm{c}_{\mathrm{i}-1} \Delta \mathrm{b} / \mathrm{b}^{0}\right. \\
\left.-\mathrm{c}_{\mathrm{i}}\left(\mathrm{c}_{\mathrm{n}-1}-\mathrm{a}_{\mathrm{n}}^{0}\right)\left(1+\Delta \mathrm{b} / \mathrm{b}^{0}\right)\right] / \mathrm{b}
\end{array}\right.
$$

Where:

$\mathrm{I}=1, \ldots, \mathrm{n}-1$

$\mathrm{c}_{0}=0$ :

$k_{n}=\left\{\begin{array}{l}\alpha_{n}\left\langle\operatorname{Inf}\left[\Delta a_{n}+a_{n}^{0}-c_{n-1}\right] / b\right. \\ \beta_{n}>\operatorname{Sup}\left[\Delta a_{n}+a_{n}^{0}-c_{n-1}\right] / b\end{array}\right.$

and where:

$k_{n+1}=\left\{\begin{array}{l}\alpha_{n+1}<\operatorname{Inf}[-N] / b \\ \beta_{n+1}>\operatorname{Sup}[-N] / b\end{array}\right.$

Now we consider the effect of $\Delta \mathrm{k}_{\mathrm{i}}(\mathrm{i}=1, \ldots \mathrm{n}), \Delta \mathrm{k}_{\mathrm{i}}$ is the function is to eliminate the chattering phenomenon of the control system and find out $\Delta \mathrm{k}_{\mathrm{i}}$ by making use of fuzzy set theory. Firstly take positive constants $\alpha$ and $\beta$, normalize switching function $\sigma$ and its rate of change against time.

Suppose Eq.12 and 13:

$\sigma_{\mathrm{n}}=\alpha . \sigma$

$\sigma_{\mathrm{n}}=\beta . \sigma$

The input variable of the fuzzy controller is: $\sigma_{\mathrm{n}} \operatorname{sign}\left(\mathrm{x}_{1}-\mathrm{Tx}_{0}-\mathrm{rK}_{\mathrm{F}}\right), \dot{\sigma}_{\mathrm{n}} \operatorname{sign}\left(\mathrm{x}_{1}-\mathrm{Tx}_{0}-\mathrm{rK}_{\mathrm{F}}\right), \sigma_{\mathrm{n}} \operatorname{sign}\left(\mathrm{x}_{\mathrm{i}}\right)$ and $\dot{\sigma}_{n} \operatorname{sign}\left(x_{i}\right)(i=2, \ldots n)$, the output of the controller is $\Delta \mathrm{k}_{\mathrm{i}}$.

Secondly, define the language value of $\sigma_{n}$ and $\dot{\sigma}_{n}$ as $\mathrm{P}, \mathrm{Z}, \mathrm{N}: \Delta \mathrm{k}_{\mathrm{i}}$ is language value as $\mathrm{PB}, \mathrm{PM}$, $\mathrm{PS}, \mathrm{ZE}, \mathrm{NS}, \mathrm{NM}, \mathrm{NB}$; as well as their subordinate functions as in Fig. 2-4:

Define the fuzzy control regularity Table 1 .

According to the above form, use the fuzzy calculation method introduced in (Klir and Youn, 1995) and gravity method to turn fuzzy output into precise control quantity Eq. 14:

$$
\Delta \mathrm{k}_{\mathrm{i}}=\left(\int \Delta \mathrm{k}_{\mathrm{i}} \tilde{\mu}_{\Delta \mathrm{k}_{\mathrm{i}}} \mathrm{d} \Delta \mathrm{k}_{\mathrm{i}}\right) /\left(\int \tilde{\mu}_{\Delta \mathrm{k}_{\mathrm{i}}} \mathrm{d} \Delta \mathrm{k}_{\mathrm{i}}\right)
$$

- $\sigma_{\mathrm{n}} \leq-\frac{1}{3}, \dot{\sigma}_{\mathrm{n}} \leq-\frac{1}{3} ;$ it is easy to get $\mathrm{k}_{\mathrm{i}}=1$

- $\quad \sigma_{\mathrm{n}} \leq-\frac{1}{3},-\frac{1}{3}\left\langle\dot{\sigma}_{\mathrm{n}} \leq 0 ; \sigma_{n}(\mathrm{~N}), \dot{\sigma}_{n}(\mathrm{~N}, \mathrm{Z})\right.$

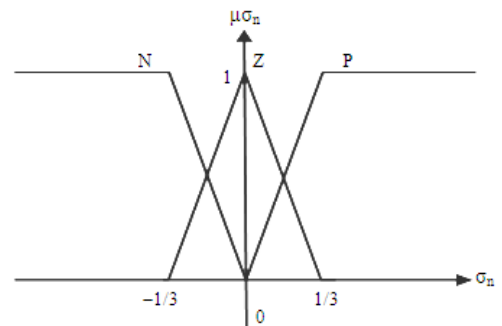

Fig. 2: The subordinate function of $\sigma_{\mathrm{n}}$

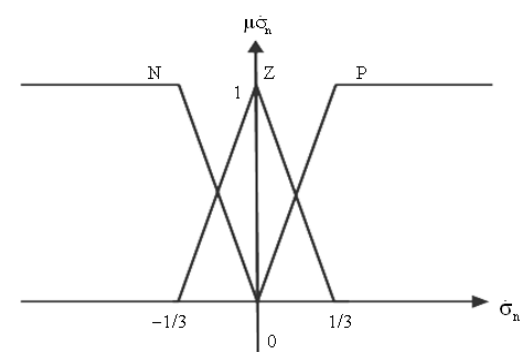

Fig. 3: The subordinate function of $\dot{\sigma}_{n}$

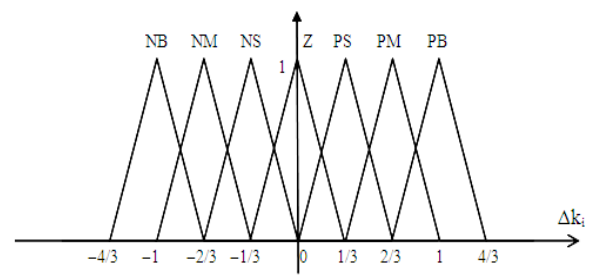

Fig. 4: The subordinate function of $\Delta \mathrm{k}_{\mathrm{i}}$

Table 1: Fuzzy control regularity

\begin{tabular}{llll}
\hline & $\mathrm{N}$ & $\mathrm{Z}$ & $\mathrm{P}$ \\
\hline $\mathrm{N}$ & $\mathrm{PB}$ & $\mathrm{PM}$ & $\mathrm{PS}$ \\
$\mathrm{Z}$ & $\mathrm{PS}$ & $\mathrm{ZE}$ & $\mathrm{NS}$ \\
$\mathrm{P}$ & $\mathrm{NS}$ & $\mathrm{NM}$ & $\mathrm{NB}$ \\
\hline
\end{tabular}

The subordinate function of $\Delta \mathrm{k}_{\mathrm{i}} \quad(\mathrm{PB}, \mathrm{PM})$ corresponding to is shown in (Phakamach, 2007).

Thus, points $\mathrm{P}_{1}$ and $\mathrm{P}_{2}$ 's abscissa are:

$$
\dot{\sigma}_{\mathrm{n}}+\frac{2}{3}, \dot{\sigma}_{\mathrm{n}}+1
$$

$\mathrm{P}_{3}$ and $\mathrm{P}_{4}$ 's abscissas are:

$$
-\dot{\sigma}_{\mathrm{n}}+\frac{2}{3}, \dot{\sigma}_{\mathrm{n}}+\frac{4}{3}
$$

Then Eq. 15:

$$
\Delta \mathrm{k}_{\mathrm{i}}=\frac{-\frac{5}{2} \dot{\sigma}_{\mathrm{n}}^{2}-\frac{7}{6} \dot{\sigma}_{\mathrm{n}}+\frac{2}{9}}{-3 \dot{\sigma}_{\mathrm{n}}^{2}-\dot{\sigma}_{\mathrm{n}}+\frac{1}{3}}
$$




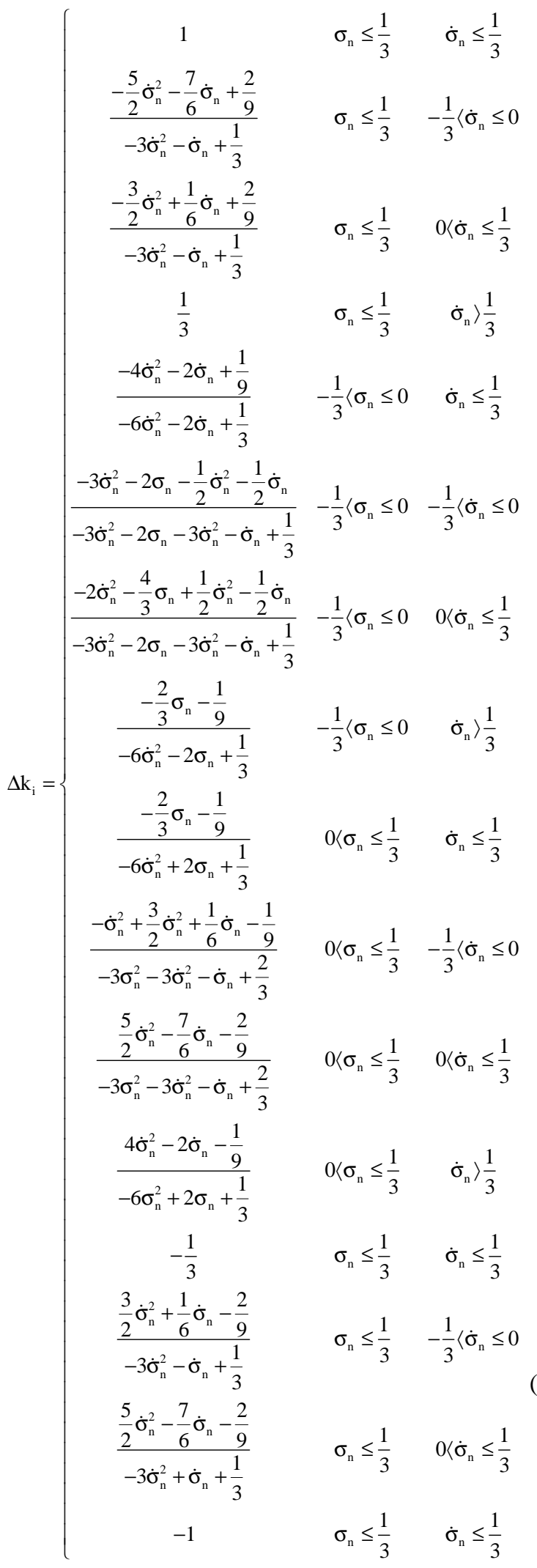

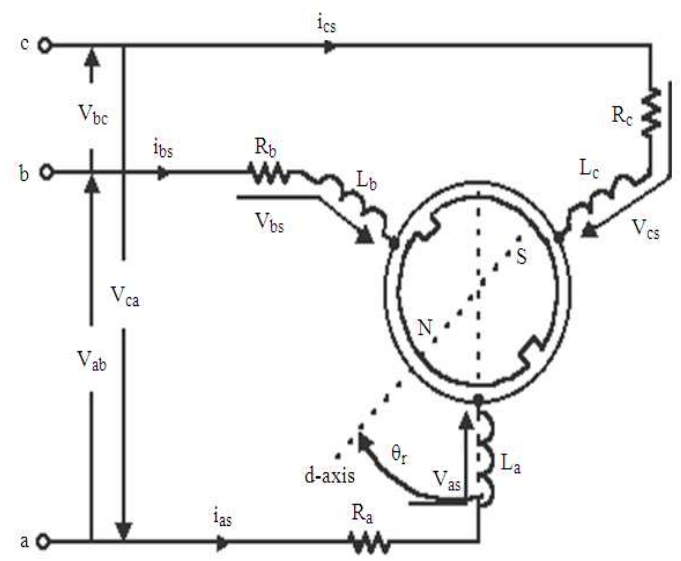

Fig. 5: The brushless DC servomotor modeling

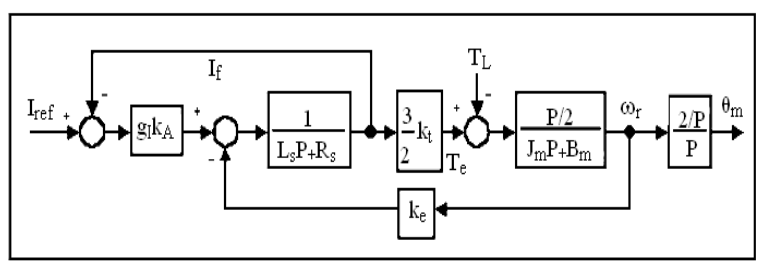

Fig. 6: Dynamic model of the brushless DC servomotor with current controlled loop

Using the same method we get the precise output $\Delta \mathrm{k}_{\mathrm{i}}$ under other circumstances to be:

for $\mathrm{i}=1, \quad \sigma_{\mathrm{n}}$ is $\sigma_{\mathrm{n}} \operatorname{sign}\left(\mathrm{x}_{1}-\mathrm{Tx}_{0}-\mathrm{rK}_{\mathrm{F}}\right)$ and $\dot{\sigma}_{\mathrm{n}}$ is $\dot{\sigma}_{\mathrm{n}} \operatorname{sign}\left(\mathrm{x}_{1}-\mathrm{Tx}_{0}-\mathrm{rK}_{\mathrm{F}}\right)$; for $\mathrm{i}=1, \sigma_{\mathrm{n}}$ is $\sigma_{\mathrm{n}} \operatorname{sign}\left(\mathrm{x}_{\mathrm{i}}\right)$ and $\dot{\sigma}_{\mathrm{n}}$ is $\dot{\sigma}_{\mathrm{n}} \operatorname{sign}\left(\mathrm{x}_{\mathrm{i}}\right)$. Finally, the control function of FLSMFC approach for simulate is obtained as Eq. 16:

$$
\begin{aligned}
\mathrm{U}= & \mathrm{U}_{\text {eq }}+\mathrm{k}_{1}\left(\mathrm{x}_{1}-\mathrm{Tx}_{0}-\mathrm{rK}_{\mathrm{F}}\right)+\sum_{\mathrm{i}=2}^{\mathrm{n}} \mathrm{k}_{\mathrm{i}} \mathrm{x}_{\mathrm{i}} \\
& +\mathrm{K}\left[\Delta \mathrm{k}_{\mathrm{i}}\left(\mathrm{x}_{1}-\mathrm{Tx}_{0}-\mathrm{rK}_{\mathrm{F}}\right)+\sum_{\mathrm{i}=2}^{\mathrm{n}} \Delta \mathrm{k}_{\mathrm{i}} \mathrm{x}_{\mathrm{i}}\right]
\end{aligned}
$$

Among them, $\mathrm{U}_{\mathrm{eq}}$ is given by (5), $\mathrm{k}_{\mathrm{i}}$ is given by inequality (11), $\Delta \mathrm{k}_{\mathrm{i}}$ is given by (15) and therefore, $\mathrm{U}$ is a continuous function.

Dynamics modeling of the brushless DC servomotor: The brushless DC servomotor considered is a three-phase permanent magnet synchronous motor with sinusoidal back Electromotive Force (EMF) as shown in Fig. 5 and dynamic model in Fig. 6. 


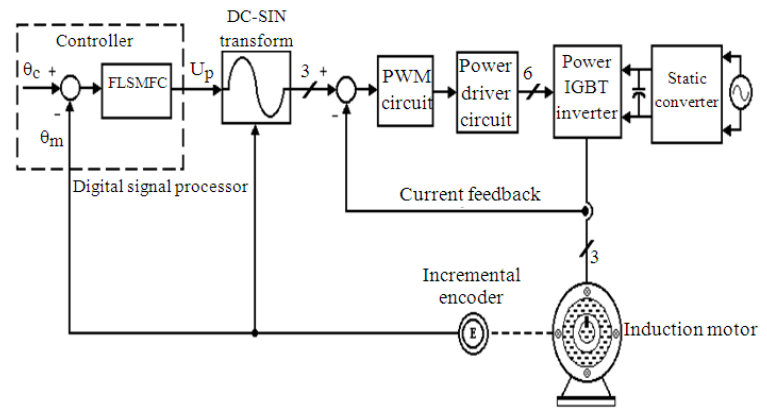

Fig. 7: The implemented of FLSMFC system

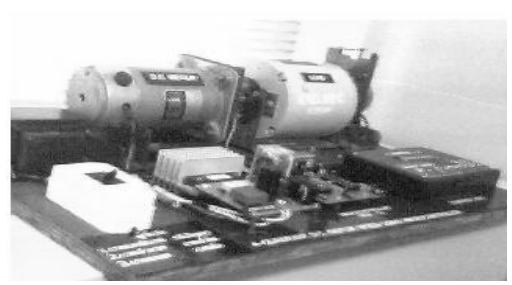

Fig. 8: The brushless DC servomotor with FLSMFC system

Table 2: Parameters of FLSMFC controller

\begin{tabular}{ll}
\hline Parameter & Value \\
\hline$\lambda_{1}, \lambda_{2}$ & $-18.426 \pm 22.947 i$ \\
$\lambda_{3}, \lambda_{4}$ & $-35.518,-16.723$ \\
$C_{1}, C_{2}$ & $1,727,63.97$ \\
$\mathrm{~K}_{1}, \mathrm{~K}_{\mathrm{F}}$ & $32.12,23.43$ \\
$\varphi_{1}, \varphi_{2}$ & $-1,-0.01$ \\
$\varphi_{3}, \varphi_{4}$ & $-0.0001,-0.001$ \\
$\mathrm{a}_{\mathrm{m} 1}, \mathrm{a}_{\mathrm{m} 2}$ & $15,000,1,320$ \\
$\mathrm{a}_{\mathrm{m} 3}, \mathrm{~b}_{\mathrm{m}}$ & $52,15,000$ \\
$\mathrm{a}_{\mathrm{p}}{ }_{0}, \mathrm{a}_{\mathrm{p} 3}{ }^{0}$ & $11,005.95,2,875$ \\
$\mathrm{~b}_{\mathrm{p}}{ }^{0}$ & $83,184.523$ \\
$\delta_{0}, \delta_{1}$ & 5,50 \\
\hline
\end{tabular}

The stator windings are identical, displaced by 120 degrees and sinusoidally distributed. The voltage equation for the stator windings can be expressed as Eq. 17:

$$
\begin{aligned}
{\left[\begin{array}{c}
\mathrm{v}_{\text {as }} \\
\mathrm{v}_{\mathrm{bs}} \\
\mathrm{v}_{\mathrm{cs}}
\end{array}\right]=} & {\left[\begin{array}{ccc}
\mathrm{R}_{\mathrm{s}} & 0 & 0 \\
0 & \mathrm{R}_{\mathrm{s}} & 0 \\
0 & 0 & \mathrm{R}_{\mathrm{s}}
\end{array}\right]\left[\begin{array}{c}
\mathrm{i}_{\mathrm{as}} \\
\mathrm{i}_{\mathrm{bs}} \\
\mathrm{i}_{\mathrm{cs}}
\end{array}\right]+\frac{\mathrm{d}}{\mathrm{dt}}\left[\begin{array}{ccc}
\mathrm{L}_{\mathrm{s}} & 0 & 0 \\
0 & \mathrm{~L}_{\mathrm{s}} & 0 \\
0 & 0 & \mathrm{~L}_{\mathrm{s}}
\end{array}\right]\left[\begin{array}{c}
\mathrm{i}_{\mathrm{as}} \\
\mathrm{i}_{\mathrm{bs}} \\
\mathrm{i}_{\mathrm{cs}}
\end{array}\right] } \\
& +\omega_{\mathrm{r}} \mathrm{k}_{\mathrm{e}}\left[\begin{array}{c}
\sin \left(\theta_{\mathrm{r}}\right) \\
\sin \left(\theta_{\mathrm{r}}-2 \pi / 3\right) \\
\sin \left(\theta_{\mathrm{r}}+2 \pi / 3\right)
\end{array}\right]
\end{aligned}
$$

Where:

$$
\begin{array}{ll}
\mathrm{v}_{\mathrm{as}}, \mathrm{v}_{\mathrm{bs}}, \mathrm{v}_{\mathrm{cs}} & =\text { The applied stator voltage } \\
\mathrm{i}_{\mathrm{as}}, \mathrm{i}_{\mathrm{bs}}, \mathrm{i}_{\mathrm{cs}} & =\text { The applied stator currents } \\
\mathrm{R}_{\mathrm{s}} & =\text { The resistance of each stator winding } \\
\mathrm{L}_{\mathrm{s}} & =\text { The inductance of the stator winding } \\
\omega_{\mathrm{r}} & =\text { The electrical motor angular velocity } \\
\theta_{\mathrm{r}} & =\text { The electrical rotor angular displacement } \\
\mathrm{k}_{\mathrm{e}} & =\text { The voltage constant }
\end{array}
$$

Table 3: Machine parameters FLSMFC controller

\begin{tabular}{lll}
\hline Parameter & Value & Dimension \\
\hline $\mathrm{P}$ & 8 & pole \\
$\mathrm{R}_{\mathrm{s}}$ & 0.1 & $\Omega$ \\
$\mathrm{L}_{\mathrm{s}}$ & 0.002 & $\mathrm{H}$ \\
$\mathrm{K}_{\mathrm{A}}$ & 6.5 & dimensionless \\
$\mathrm{g}_{\mathrm{I}}$ & $1 \times 10^{4}$ & dimensionless \\
$\mathrm{B}_{\mathrm{m}}$ & 0.00 & $\mathrm{~N}-\mathrm{sec}^{-2}$ \\
$\mathrm{~J}_{\mathrm{m}}$ & 0.0014 & $\mathrm{Kg}-\mathrm{m}^{2}$ \\
$\mathrm{~K}_{\mathrm{e}}$ & 0.43 & $\mathrm{~V}-\mathrm{s} / \mathrm{rad}$ \\
$\mathrm{K}_{\mathrm{t}}$ & 0.43 & $\mathrm{~N}-\mathrm{m} / \mathrm{A}$ \\
\hline
\end{tabular}

The FLSMFC for motor drives: The implementation of FLSMFC system is shown in Fig. 7 and its block diagram is shown in Fig. 8. The nominal values of the FLSMFC controller and the machine parameters are listed in Table 2 and 3, respectively. The simplified dynamic model of the motor for position control can be described as Eq. 18:

$\dot{\mathrm{x}}_{\mathrm{p} 1}=\mathrm{x}_{\mathrm{p} 2}, \dot{\mathrm{x}}_{\mathrm{p} 2}=\mathrm{x}_{\mathrm{p} 3}$,
$\dot{\mathrm{x}}_{\mathrm{p} 3}=-\mathrm{a}_{\mathrm{p} 1} \mathrm{x}_{\mathrm{p} 1}-\mathrm{a}_{\mathrm{p} 2} \mathrm{x}_{\mathrm{p} 2}-\mathrm{a}_{\mathrm{p} 3} \mathrm{x}_{\mathrm{p} 3}+\mathrm{b}_{\mathrm{p}} \mathrm{U}_{\mathrm{p}}-\mathrm{f}(\mathrm{t})$

Where:

$\mathrm{a}_{\mathrm{p} 1}=0$

$\mathrm{a}_{\mathrm{p} 2}=\frac{\left(\mathrm{R}_{\mathrm{s}}+\mathrm{g}_{\mathrm{I}} \mathrm{k}_{\mathrm{A}}\right) \mathrm{B}_{\mathrm{m}}+\frac{3}{4} \mathrm{Pk}_{\mathrm{t}} \mathrm{k}_{\mathrm{e}}}{\mathrm{L}_{\mathrm{s}} \mathrm{J}_{\mathrm{m}}}$

$\mathrm{a}_{\mathrm{p} 3}=\frac{\left(\mathrm{R}_{\mathrm{s}}+\mathrm{g}_{\mathrm{I}} \mathrm{k}_{\mathrm{A}}\right)}{\mathrm{L}_{\mathrm{s}}}+\frac{\mathrm{B}_{\mathrm{m}}}{\mathrm{J}_{\mathrm{m}}}$

$\mathrm{b}_{\mathrm{p}}=\frac{\left(\frac{3}{2} \mathrm{~g}_{\mathrm{I}} \mathrm{k}_{\mathrm{A}} \mathrm{k}_{\mathrm{t}}\right)}{\mathrm{L}_{\mathrm{s}} \mathrm{J}_{\mathrm{m}}}$

$f(t)=\frac{\left(R_{s}+g_{I} k_{A}\right)}{J_{m} L_{s}} T_{L}+\frac{1}{J_{m}} \dot{T}_{L}$

and where:

$\mathrm{x}_{\mathrm{p} 1}=\theta_{\mathrm{m}}=$ The mechanical angular angle of the rotor

$\mathrm{U}_{\mathrm{m}}=\theta_{\mathrm{c}}=$ Desired position

$\mathrm{U}_{\mathrm{P}} \quad=$ The control input of the plant

The reference model is chosen as Eq. 19:

$\dot{\mathrm{x}}_{\mathrm{m} 1}=\mathrm{x}_{\mathrm{m} 2}, \dot{\mathrm{x}}_{\mathrm{m} 2}=\mathrm{x}_{\mathrm{m} 3}$,

$\dot{\mathrm{x}}_{\mathrm{m} 3}=-\mathrm{a}_{\mathrm{m} 1} \mathrm{x}_{\mathrm{m} 1}-\mathrm{a}_{\mathrm{m} 2} \mathrm{x}_{\mathrm{m} 2}-\mathrm{a}_{\mathrm{m} 3} \mathrm{x}_{\mathrm{m} 3}+\mathrm{b}_{\mathrm{m}} \mathrm{U}_{\mathrm{m}}$

Defining $\mathrm{e}_{\mathrm{i}}=\mathrm{x}_{\mathrm{pi}}-\mathrm{x}_{\mathrm{mi}} ; \quad(\mathrm{i}=1,2,3)$, the FLSMFC system can be represented as $\dot{\mathrm{e}}_{1}=\mathrm{e}_{2}, \dot{\mathrm{e}}_{2}=\mathrm{e}_{3}$ and Eq. 20:

$$
\begin{aligned}
\dot{\mathrm{e}}_{3}= & -\mathrm{a}_{\mathrm{p} 1} \mathrm{e}_{1}-\mathrm{a}_{\mathrm{p} 2} \mathrm{e}_{2}-\mathrm{a}_{\mathrm{p} 3} \mathrm{e}_{3} \\
& +\left(\mathrm{a}_{\mathrm{m} 1}-\mathrm{a}_{\mathrm{p} 1}\right) \mathrm{x}_{\mathrm{m} 1}+\left(\mathrm{a}_{\mathrm{m} 2}-\mathrm{a}_{\mathrm{p} 2}\right) \mathrm{x}_{\mathrm{m} 2} \\
& +\left(\mathrm{a}_{\mathrm{m} 3}-\mathrm{a}_{\mathrm{p} 3}\right) \mathrm{x}_{\mathrm{m} 1}-\mathrm{b}_{\mathrm{m}} \mathrm{U}_{\mathrm{m}}+\mathrm{b}_{\mathrm{p}} \mathrm{U}_{\mathrm{p}}-\mathrm{f}(\mathrm{t})
\end{aligned}
$$

Following the design procedure we have the control law to implement as Eq. 21: 


$$
\begin{aligned}
\mathrm{U}_{\mathrm{P}}= & \left\{\mathrm{c}_{1}\left(\mathrm{~K}_{1} \dot{\mathrm{z}}\right)+\mathrm{a}_{\mathrm{p} 1}^{0} \mathrm{e}_{1}+\mathrm{a}_{\mathrm{p} 2}^{0} \mathrm{e}_{2}-\left[\left(\mathrm{a}_{\mathrm{m} 1}-\mathrm{a}_{\mathrm{p} 1}^{0}\right) \mathrm{x}_{\mathrm{m} 1}\right.\right. \\
& \left.\left.+\left(\mathrm{a}_{\mathrm{m} 2}-\mathrm{a}_{\mathrm{p} 2}^{0}\right) \mathrm{x}_{\mathrm{m} 2}+\left(\mathrm{a}_{\mathrm{m} 3}-\mathrm{a}_{\mathrm{p} 3}^{0}\right) \mathrm{x}_{\mathrm{m} 3}+\mathrm{b}_{\mathrm{m}} \mathrm{U}_{\mathrm{m}}\right)\right] \\
& \left.+\left(\mathrm{c}_{2}-\mathrm{a}_{3}^{0}\right)\left[\mathrm{c}_{1}\left(\mathrm{e}_{1}-\mathrm{K}_{1} \mathrm{z}-\mathrm{rK}_{\mathrm{F}}\right)+\mathrm{c}_{2} \mathrm{e}_{2}\right]\right\} / \mathrm{b}^{0} \\
& +\left(\phi_{1}\left|\mathrm{e}_{1}-\mathrm{K}_{1} \mathrm{z}-\mathrm{rK}_{\mathrm{F}}\right|+\phi_{2}\left|\mathrm{e}_{2}\right|+\phi_{3}\left|\mathrm{e}_{3}\right|+\phi_{4}\right) \mathrm{M}_{\delta}(\sigma)
\end{aligned}
$$

The switching function, $\sigma$ from (2), is Eq. 22:

$\sigma=c_{1}\left(e_{1}-K_{1} Z-K_{F}\right)+c_{2} e_{2}+e_{3} ; r=U_{m}$

\section{MATERIALS AND METHODS}

To verify the performance of a proposed scheme, a prototype implementation of the brushless DC servomotor driver as shown in Fig. 8 consists of a power amplifier and control stage.

The power amplifier state includes an intelligent power module and current detector circuit. The control stage is based on a DSP-TMS320F280. It can perform all necessary controls such as the position, speed, acceleration and FLSMFC e.t.a. The 18-bit DAC, 18-b $\mathrm{ADC}$ and 32-b decoder circuits are necessary for data translation. The executive file is downloaded from the PC to the DSP through an RS-232 data link. The sampling period using in this scheme is $55 \mu \mathrm{s}$.

\section{RESULTS AND DISCUSSION}

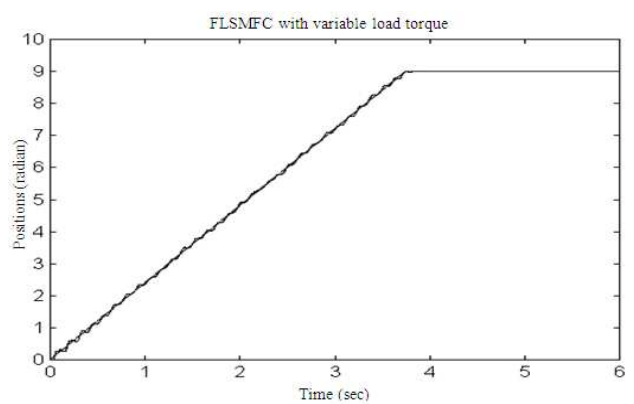

(a)

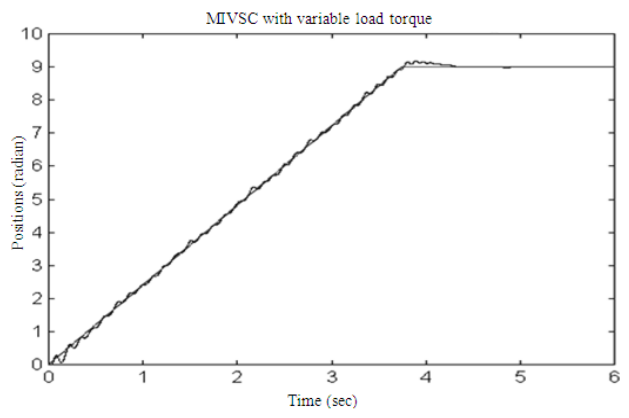

(b)

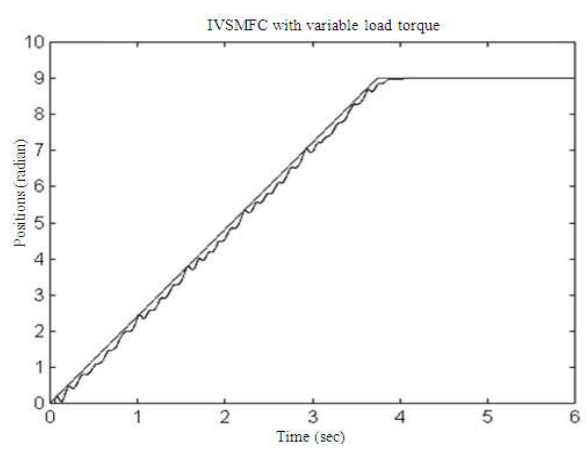

(c)

Fig. 9: Comparison of ramp position tracking

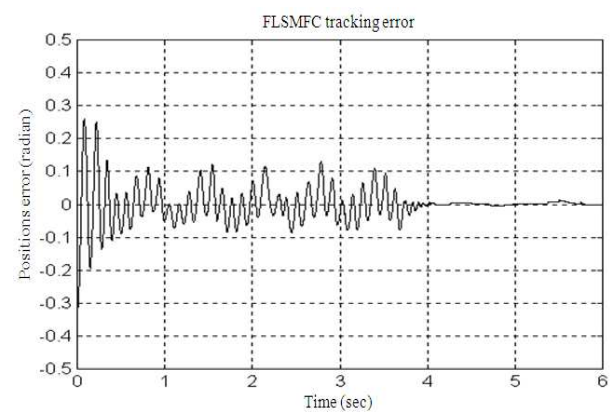

(a)

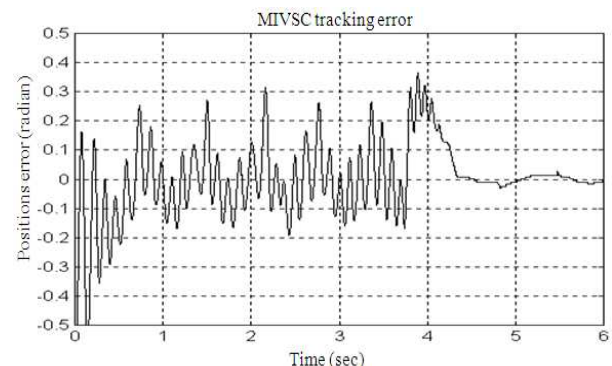

(b)

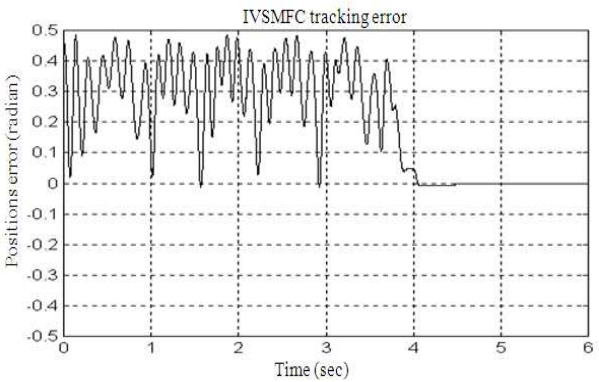

(c)

Fig. 10: Comparison of position tracking error

The robustness of the proposed FLSMFC approach against large variations of plant parameters and external 
load disturbances has been implemented for demonstration. The experimental results of the dynamic response are shown in Fig. 9, where a ramp command is introduced and the motor is applied with a variable load torque and parameters variation. The results are compared with obtained from the IVSMFC and MIVSC approaches, respectively. Figure 10 compares the position tracking errors.

It is clear from the curves that FLSMFC can track the command input extremely well during steady state as well as transient periods. From the observations, it is obvious the proposed approach can achieve accurate and robust responses. Among others, the FLSMFC approach gives the minimum tracking error.

\section{CONCLUSION}

In this study, the FLSMFC approach is presented. It exhibits good feature of the conventional IVSC, such as robustness in the face of model error and parameter variations. The application of FLSMFC to the brushless DC servomotor position control system has illustrated that the FLSMFC method can improve the tracking performance by 68 and $85 \%$ when compared to the MIVSC and IVSMFC approaches, respectively. Moreover, the proposed approach can achieve accurate and fast position servo tracking in the face of large parameter variations and external load disturbances. It is a considerably robust and practical control law for a servomechanism system.

\section{REFERENCES}

Krause, P.C., O. Wasynezuk and S.D. Sudhoff, 2002. Analysis of Electric Machinery and Drive Systems. 2nd Edn., IEEE Press, New York, ISBN-10: 047114326X, pp: 613.

Utkin, V.I., J. Guldner and J. Shi, 2009. Sliding Mode Control in Electro-Mechanical Systems. 2nd Edn., CRC Press, London, New York, ISBN-10: 1420065602, pp: 485.

Hung, J.Y., W. Gao and J.C. Hung, 1993. Variable structure control: A survey. IEEE, Trans. Ind. Elect., 40: 2-22. DOI: 10.1109/41.184817

Chern, T.L. and J.S. Wang, 1995. DSP based integral variable structure control for DC motor servo drivers. IEE Proc. Control Theor. Appli., 142: 444-450. DOI: 10.1049/ip-cta:19952087
Chern, T.L. and J. Chang, 1997. DSP-based induction motor drives using integral variable structure model following control approach. Proceedings of the IEEE International Electric Machines and Drives, Conference, May 18-21, IEEE Xplore Press, Milwaukee, WI, USA, pp: MC2/9.1MC2/9.3. DOI: 10.1109/IEMDC.1997.604172

Chen, C.Y., M.H.M. Cheng and C.F. Yang, 2009. Modified sliding mode speed control of brushless DC motor using quantized current regulator. Proceedings of the 4th International Conference Innovative Computing, Information and Control, 2009, Dec. 7-9, IEEE Xplore Press, Kaohsiung, pp: 926-929. DOI: 10.1109/ICICIC.2009.267

Phakamach, P. and C. Akkaraphong, 2003. The design and implementation of an induction motor driver using a sliding mode model following control with sinusoidal command input. Proceedings of the 5th International Conference on Power Electronics and Drive Systems, Nov. 17-20, IEEE Xplore Press, Thailand, pp: 1591-1595. DOI: 10.1109/PEDS.2003.1283227

Thongchai, S., 2002. Behavior-based learning fuzzy rules for mobile robots. Proceedings of the American Control Conference, May 8-10, IEEE Xplore Press, Alaska, USA, pp: 995-1000. DOI: 10.1109/ACC.2002.1023148

Thongchai, S., M. Goldfarb, N. Sarkar and K. Kawamura, 2001. A frequency modeling method of rubbertuators for control application in an IMA framework. Proceedings of the American Control Conference, Jun. 25-27, IEEE Xplore Press, Virginia, USA., pp: 1710-1714. DOI: 10.1109/ACC.2001.945977

Klir, G.J. and B. Youn, 1995. Fuzzy Sets and Fuzzy Logic: Theory and Applications. 1st Edn., PrenticeHall, Upper Saddle River, USA., ISBN-10: 0131011715, pp: 574.

Phakamach, P. 2007. A variable structure control based on fuzzy logic algorithm with an integral compensation for a dc servomotor drives. Proceedings of the International Multi Conference of Engineers and Computer Scientists, Mar. 21-23, Newswood Limited, Hong Kong, pp: 1510-1515. 